\title{
RELIGION, EDUCATION, AND THE SUPREME COURT
}

\author{
Charles Fahy* $_{\text {* }}$
}

This discussion takes it as fundamental that man is more than a rational being; that he possesses a soul, and that the soul is immortal. The sum of these premises is for present purposes that the development of a spiritual life, that is, the education of the soul, is deemed by a large part of our population to be an essential part of the education of man. He does not live by bread alone; and if the soul lives on after death, if death is but a phase of eternal life, the prime place of the soul in life becomes obvious. To omit from education consideration of the spiritual, therefore, is unacceptable to one who believes these truths.

Religion in the sense in which it is used here is not the mere study of religious beliefs as historical or current facts. Religion is the development of the spiritual life of the individual, the effort to perfect one's relation with God from day to day and year to year. None of this is of great interest to one who rejects religion. To one who accepts it, however, the concern is all important. He cannot be indifferent to the problem of religion in relation to and as a part of education. To be indifferent would be to be untrue to his own conception of his nature as a human being. $\mathrm{He}$ must seek the means of practicing his religion, for religion itself requires this. Further, like all education, religious education, indeed religion itself, is a developing process with the individual. It is not static. It is not like learning to add a column of figures and to reach the sum of them, or like learning to spell a word. It is a never-ending life and growth, seeking perfection, however imperfectly. The natural development of the individual therefore calls for religious or spiritual education as well as education in the purely secular sense.

All will agree that education in the more limited and secular sense must be available and compulsory up to a certain point. All should agree, too, in our climate of freedom in religious matters, that this compulsory secular education cannot be accompanied by a commingling of religious or sectarian education against the will of the individual. The problem is as to the proper division of responsibility, particularly in the case of one who seeks education in the fuller sense which includes the spiritual. The problem becomes one of adjustment-adjustment within the governmentâl scheme and between government and non-government.

In the natural as well as in the supernatural order the family is the fundamental

- Former General Counsel, National Labor Relations. Board; former Solicitor General of the United States; former Legal Adviser to the Department of State. Member of the New Mexico and District of Columbia bars. 
human unit when we go beyond the individual. Since the family in ordinary course is composed of parents and children, the first responsibility for education rests upon the parents. In the community, as children grow they are sent by their parents to institutions established for the purpose of carrying forward the parental responsibility in what might be called a delegated manner. The professional or avocational educator is a specialist who thus takes over in the common interests of parents and of the community and, indeed, of the church also, because the church has a special responsibility of its own to "Go forth and teach all nations." The institutional school as distinguished from the home may accordingly be sponsored by the government or parents, or by other groups, including religious groups. Until comparatively recent times the church and religious orders under her canopy were by far the principal centers of education, both lay and religious, and to these is still owed the greatest educational debt of the Christian Era. With the passage of time and under changed conditions a greater proportion of educational facilities has become independent of church auspices. This is true in the United States with the development of the public school system.

There is accordingly a three-fold obligation with respect to education: the parental obligation, the obligation of the state, and the obligation of the church or of religious groups. These obligations are not necessarily in entirely insulated compartments and the problem of government is properly to permit the three-fold responsibilities to be adequately fulfilled without infringement of one group upon the appropriate domain of the other; that is, to maintain the proper separation of functions and at the same time to permit the fulfillment of responsibility. In this division and accommodation of responsibilities the nonreligious person has, as against the state, a "right" to be a disbeliever." His freedom so to be is recognized under the law. But the right of the believer to believe, and to exercise his religion, is also protected and may not be weakened under the guise of protection of another's freedom to disbelieve.

\section{I}

\section{ResponsibILITY OF THE PARENT}

The parental responsibility includes both secular and religious education. The right of the parent to guide the education of the child, notwithstanding the presence of compulsory school laws under general systems of public education, has been emphasized repeatedly by the Supreme Court. It is the basis of several rulings under the Fifth and Fourteenth Amendments, striking down statutes barring the teaching of a particular foreign language in the public schools ${ }^{2}$ or unduly restricting the operation of private, so-called foreign-language schools. ${ }^{3}$ This constitutional protec-

\footnotetext{
${ }^{2}$ See Wilfrid Parsons, The First Fretdom: Considerations on Church and State in the United STATES I15 (1948).

${ }^{2}$ Meyer v. Nebraska, 262 U. S. 390 (1923); Bartels v. Iowa, 262 U. S. 404 (1923).

${ }^{3}$ Farrington v. Tushige, 273 U. S. 284 (1927); Stainback v. Mo Hock Ke Lok Po, 74 F. Supp. 852 (D. Hawaii 1947), appeal dismissed, United States Supreme Court, March 14, 1948.
} 
tion of the parental right was at the heart of the notable decision in the Oregon school case, holding unconstitutional under the Fourteenth Amendment a state statute prohibiting parents from sending their children to Catholic parochial schools, where the children were taught the usual public school curriculum in addition to receiving systematic religious instruction and moral training according to the tenets of their church. 4 The unanimous opinion in that case has never been questioned by the Supreme Court. It was recently cited with approval in the majority opinion written by Justice Black in Everson v. Board of Education. ${ }^{5}$

The classic statement of the Court in the Oregon school case merits repetition:

Under the doctrine of Meyer v. Nebraska . . we think it entirely plain that the Act of 1922 unreasonably interferes with the liberty of parents and guardians to direct the upbringing and education of children under their control. As often heretofore pointed out, rights guaranteed by the Constitution may not be abridged by legislation which has no reasonable relation to some purpose within the competency of the state. The fundamental theory of liberty upon which all governments in this Union repose excludes any general power of the state to standardize its children by forcing them to accept instruction from public teachers only. The child is not the mere creature of the state; those who nurture him and direct his destiny have the right, coupled with the high duty, to recognize and prepare him for additional obligations. ${ }^{6}$

The parental right to guide the education of the child is thus protected by the due process clauses of the Fourteenth and Fifth Amendments, regardless of whether the child is educated, in the discretion of the parent, in a public school or in a private school meeting public standards. This parental right, where religious education is involved, although clothed in the language of due process of law in the Oregon and similar cases, is essentially an aspect of the free exercise of religion under the second clause of the First Amendment, as elaborated in the more recent decisions of the Supreme Court. In the flag-salute decision the Court declared:

The State asserts power to condition access to public education on making a prescribed sign and profession and at the same time to coerce attendance by punishing both parent and child. The latter stand on a right of self-determination in matters that touch individual opinion and personal attitude....

If there is any fixed star in our constitutional constellation, it is that no official, high or petty, can prescribe what shall be orthodox in politics, nationalism, religion, or other matters of opinion or force citizens to confess by word or act their faith therein. If there are any circumstances which permit an exception, they do not now occur to us.

We think the action of the local authorities in compelling the flag salute and pledge transcends constitutional limitations on their power and invades the sphere of intellect and spirit which it is the purpose of the First Amendment to our Constitution to reserve from all official control. ${ }^{7}$

4 Pierce v. Society of Sisters, 268 U. S. 510 (1925).

330 U. S. I, 18 (1947): "This Court has said that parents may, in the discharge of their duty under state compulsory education laws, send their children to a religious rather than a public school if the school meets the secular educational requirements which the state has power to impose. See Pierce v. Society of Sisters, 268 U. S. 5 I0."

" 268 U. S. 510, 534-535 (I925).

7 Board of Education v. Barnette, 379 U. S. 624, 630-63r, 642 (1943). 


\section{This was followed by Prince v. Massachusetts, where the Court said:}

The rights of children to exercise their religion, and of parents to give them religious training and to encourage them in the practice of religious belief, as against preponderant sentiment and assertion of state power voicing it, have had recognition here, most recently in West Virginia State Board of Education v. Barnette, 319 U. S. 624. Previously in Pierce v. Society of Sisters, 268 U. S. 5ro, this Court had sustained the parent's authority to provide religious with secular schooling, and the child's right to receive it, as against the state's requirement of attendance at public schools. And in Meyer v. Nebraska, 262 U. $\dot{\text { S. }}$ 390 , children's rights to receive teaching in languages other than the nation's common tongue were guarded against the state's encroachment. It is cardinal with us that the custody, care and nurture of the child reside first in the parents, whose primary function and freedom include preparation for obligations the state can neither supply nor hinder. Pierce v. Society of Sisters, supra. And it is in recognition of this that these decisions have respected the private realm of family life which the state cannot enter. ${ }^{8}$

\section{II}

\section{Responsibility of the State aNd the Church}

\section{A. Accommodation of Parental, State, and Church Obligations}

Let us reiterate at this point that in the United States the responsibility of government to provide education up to a minimum level does not include a responsibility to engage in sectarian religious education itself. Nevertheless, recognition by government of the primary parental responsibility requires the government to fulfill its own obligation regarding secular education in a manner which does not interfere with the right of the parent or of the child to secure religious education, including education of a particular religious character as distinct from education about religion. There must be a sensible accommodation, one with the other. The duty of the

${ }^{8} 321$ U. S. 158, 165-166 (1944). The parents' freedom in matters of education of the child was thus reiterated in the strongest terms. The Court went on to hold that neither freedom of religion under the First and Fourteenth Amendments nor a claim of parental right under the due process clause of the Fifth and Fourteenth Amendments precluded application of a general state statute against children's offering newspapers, periodicals, or merchandise for sale in any street or public place. The parent and children in question were all members of Jehovah's Witnesses, engaged in selling religious tracts on the streets, after school hours. The Court's opinion stated that "the due process claim, as made and perhaps necessarily, extends no further than that to freedom of religion, since in the circumstances all that is comprehended in the former is included in the latter." $I d$. at 164, n. 8 .

'See Jackson J., concurring, in McCollum v. Board of Education, 333 U. S. 203, 235-236 (1948): "Perhaps subjects such as mathematics, physics, or chemistry are, or can be, completely secularized. But it would not seem practical to teach either practice or appreciation of the arts if we are to forbid cxposure of youth to any religious influences. Music without sacred music, architecture minus the cathedral, or painting without the scriptural themes would be eccentric and incomplete, even from a secular point of view. Yet the inspirational appeal of religion in these guises is often stronger than in forthright sermon. Even such a 'science' as biology raises the issue between evolution and creation as an explanation of our presence on this planet. Certainly a course in English literature that omitted the Bible and other powerful uses of our mother tongue for religious ends would be pretty barren. And I should suppose it is a proper, if not an indispensable, part of preparation for a worldly life to know the roles that religion and religions have played in the tragic story of mankind. The fact is that, for good or for ill, nearly everything in our culture worth transmitting, everything which gives meaning to life, is saturated with religious influences, derived from paganism, Judaism, Christianity-both Catholic and Protestant-and other faiths accepted by a large part of the world's peoples. One can hardly respect a system of education that would leave the student wholly ignorant of the currents of religious thought that move the world society for a part in which he is being prepared." 
church to teach religion must also, in a society such as ours, which recognizes and guarantees freedom of religion, be given scope for fulfillment without government hindrance or control. Indeed, government may properly encourage religion provided no particular sect is given government favor and provided the exercise of religious freedom is preserved. This encouragement (along with freedom to do without) has been in fact the situation in the United States from the beginning. ${ }^{10}$

\section{B. Contemporaneous Background of the First Amendment}

The climate of the American revolutionary period, including the period of consitutional development, was fundamentally religious. The Declaration of Independence, the handiwork of Jefferson to a large degree but signed by fifty-five representatives of the colonial people, affirmatively shows this. Four times it makes reference to the religious basis of the Declaration's approach to the problem with which it deals. In these four separate references is contained a true philosophical appreciation of man's relation to God and, through Him, to one another, and of the relation of the state to the individual. In the opening sentence of the Declaration reference is made to the equal station to which the American people were entitled by the laws of nature and of nature's God, thus recognizing God as the source of the laws of nature. God is then referred to as the Creator Who has endowed man with certain inalienable rights which are his by virtue of his own nature and of which the state may not deprive him. The signers then appealed to God as the Supreme Judge of the world, and lastly $\mathrm{He}$ is petitioned as the Divine Providence, in whom the trust of our founders is reposed.

No one can appeal to Jefferson and his co-signers of the Declaration as the architects of a nonreligious America, or as indifferent to religion. In the supreme product of Jefferson's versatile and extraordinary qualities he rests his governmental philosophy upon a truly religious relationship of man to God, of man to man through the Creator of all, and of government to man through the Supreme Judge of all; and he exemplifies the relationship in the Declaration's petition to the Divine Providence. This is entirely consistent with his fierce determination that no religion should be forced upon anyone and that the individual must be utterly free to be or not to be religious and, if the former, freely to choose his religion.

Nothing occurred after the Declaration through the period which saw the adoption of the Constitution evidencing any change in the fundamentally religious climate of early America and of its founders. The Northwest Ordinance, for the government of the Territory of the United States northwest of the Ohio River, was adopted in 1787 by the Congress of the United States under the Articles of Confederation. It provided:

No person, demeaning himself in a peaceable and orderly manner, shall ever be molested on account of his mode of worship, or religious sentiments, in the said territory.

${ }^{10}$ See Holy Trinity Church v. United States, 143 U. S. 457, 465-472 (1892). 
Religion, morality, and knowledge being necessary to good government and the happiness of mankind, schools and the means of education shall forever be encouraged.11

The last quoted provision is a revealing expression by these early American statesmen as to the relation of education to religion. It assumes that education includes encouragement of religion.

Then comes the Constitution itself. Prior to its amendment the Constitution contained only one provision touching upon religion; it is the very last substantive provision, and reads as follows:

... no religious test shall ever be required as a Qualification to any office or public Trust under the United States. ${ }^{12}$

This provision for federal neutrality regarding religion, so far as qualification for office is concerned, and, at the same time, this clear recognition of the principle of religious freedom, found fuller expression in the First Amendment to be considered in a moment. It should now be noted that the absence of provision in the original Constitution other than the barring of a religious test as a qualification for federal office reflects on the one hand the refusal of the states to grant to the new federal legislature any specific powers of control over either religion or education, ${ }^{13}$ and, on the other hand, emphasizes the concern of the framers to protect religious freedom so far as the Federal Government was concerned. Further, it emphasizes by its limitation to federal employment or trust that the states were left free even with regard to qualifications for state office. Many states, it will be remembered, had established religions and religious tests for office at this time and for years thereafter. $^{14}$

Many of the original states, however, were not content merely with the Constitutional prohibition of a religious test for federal office. They wanted more explicit restrictions upon the new federal law-making body regarding religious matters. They wished to eliminate all possible doubt as to the lack of power to establish a religion and to interfere with the free exercise thereof. ${ }^{15}$ The First Amendment provided this explicitness. The federal Congress "shall make no law respecting an establishment of religion" or "prohibiting the free exercise" of religion. Each of the two clauses of this Amendment serves a separate purpose but each at the same time is complementary to the other. The free exercise of religion protected by the second clause is supported by the prohibition in the first clause of any law respecting an establishment of religion. Such an establishment by act of Congress would necessarily interfere with religious freedom. But the freedom guaranteed by the

${ }^{11}$ I Stat. 5 I n. (July I3, I787).

12 U. S. Const. Art. VI.

13 The constitutional draftsmen never intended, however, to render unconstitutional provisions for chaplain's services, tax exemptions, or other forms of federal cooperation with all religions and religious institutions in general. See the discussion of these provisions infra.

${ }^{14}$ See Parsons, op. cit. stipra note I, at $2 \mathrm{I}-29$.

${ }^{15}$ For a detailed and penetrating analysis of the contemporaneous background of the First Amendment, see Parsons, op. cit. supra note $\mathrm{r}$, at 30 et seq. 
second clause is much broader than freedom merely from an established religion. Other interference with religious freedom is also barred to the Federal Government by the second clause.

It is indeed probable that the second clause would have been construed to prevent Congress from passing any law respecting an establishment of religion even had the first clause been omitted. But history and the times moved the first Congress to be explicit on the question of "establishment." It must be clear that the new federal legislature could not favor a particular religion and that there could be no national or established religion. Madison, who espoused the Amendments, had originally proposed the following form to cover the subject:

The civil rights of none shall be abridged on account of religious belief, nor shall any national religion be established, nor shall the full and equal rights of conscience in any manner, or on any pretext, be infringed. ${ }^{16}$

The second version, as reported from committee, read:

No religion shall be established by law, nor shall the equal rights of conscience be infringed. 17

In debate on the second version, the purpose was described as follows by Madison:

Whether the words are necessary or not, he did not mean to say, but they have been required by some of the State Conventions, who seemed to entertain an opinion that under the clause of the Constitution, which gave power to Congress to make all laws necessary and proper to carry into execution the Constitution, and the laws made under it [sic] enabled them to make laws of such a nature as might infringe the rights of conscience, and establish a national religion; to prevent these effects he presumed the amendment was intended, and he thought it as well expressed as the nature of the language would admit. ${ }^{18}$

Madison stated his view of the meaning of the provision as follows:

.... that Congress should not establish a religion, and enforce the legal observance of it by law, nor compel men to worship God in any manner contrary to their conscience. ${ }^{10}$

The provision as adopted carried into the Constitution this same meaning. There were only minor changes in language. The history of the debate demonstrates the purpose to insure against the establishment of a particular religion by the new Federal Governmnent, and of course by the second clause to prevent any other federal encroachment upon the free exercise of conscience.

It should be noted that Madison's earlier fight in Virginia was on a different and broader level. His Remonstrance there had to do with what should be the law in the State of Virginia and not with the powers of the Federal Government. His tremendous energies had been directed in the Virginia legislature, as a matter of state

${ }^{20}$ I Annals of Cong. 434 (Gales ed. I834).

${ }^{27}$ Id. at 729 .

${ }^{18}$ Id. at 730 .

${ }^{10}$ Ibid. 
and personal policy, against state payments toward religious work of Christian denominations, and to bring to an end the "established" church in Virginia. Some years later in the Federal Congress his effort was the more limited one, as he himself explained,,$^{20}$ to insure against any federal law establishing a religion or prohibiting the free exercise of religion. What if anything in addition should be done or prohibited was for the states themselves. Leading members of the Virginia legislature in fact criticized the first clause of the First Amendment because it went no further than to prohibit establishment of a national religion. ${ }^{21}$

When, therefore, the Constitution, with the First Amendment, left the hands of the framers and the first Congress, and was adopted, it provided that ( $I$ ) no religious test should be required for federal office or trust, (2) no religion should be established or (preferred) by the new government, and (3) the new government could not infringe the free exercise of religion.

State policy gradually conformed with these provisions applicable to the Federal Government. As state constitutions came into being, similar and even broader provisions were self-imposed by the states. Five states on the other hand, continued the established churches of their colonial period. ${ }^{22}$ And most significantly, the term "establishment" or its equivalent, as used in the state constitutional provisions framed in that day and atmosphere, plainly meant a state church or religion preferred over others. $^{23}$ Books of reference confirm that this was the universally accepted usage of the term; i.e., "establishment" in the sense of an established church. ${ }^{24}$

The first Congress, which framed the First Amendment, gave further substance to this interpretation by providing for chaplains' services in both Houses ${ }^{25}$ and in

${ }^{20}$ Supra p. 79.

21 Journal of Virginia Senate, 1789 6r-64 (1828).

22 Parsons, op. cit. supra note 1 , at 29 .

2s Delaware (1776): Art. 29: "There shall be no establishment of any one religious sect in this State in preference to another. . ." I Francis Thorpe, American Charters, Constitutions and Organic Laws 567 (1909).

New Hampshire ( $\left.I_{784}\right)$ : Art. VI: "And every denomination of christians demeaning themselves quietly, and as good subjects of the state, shall be equally under the protection of the law: and no subordination of any one sect or denomination to another, shall ever be established by law." 4 id. at 2454 .

New Jersey (1776): Art. XIX: "That there shall be no establishment of any one religious sect in this Province, in preference to another. ..." 5 id. at 2597.

New York (1777): Article XXXV abrogated all laws, common or statutory, which might "be construcd to establish or maintain any particular denomination of Christians or their ministers. . . . 5 id. at 2636 .

North Carolina (I776); Art. XXXIV: "There shall be no establishment of any one religious church or denomination in this State, in preference to any other . . " 5 id. at 2793.

In contrast, the South Carolina Constitution of 1778 provided in Article XXXVIII: "That all persons and religious societies who acknowledge that there is one God, and a future state of rewards and punishments, and that God is publicly to be worshipped, shall be freely tolerated. The Christian Protestant religion shall be deemed, and is hereby constituted and declared to be, the established religion of this State." 6 id. at 3255 .

The constitutions of states newly formed, as well as state constitutions re-framed, during the rgth century reflected the same understanding. E.g., Iowa Const. Art. I, 53; LA. Const. Art. 4; S. C. Const. Art. I, \$4; UTAH Const. Art. I, \$4.

24 Webster's New International Dictionary 874 (2d. ed. 1948); 8 Encyc. Britannica 726 (I4th ed. I937).

25 I AnNals of Cong. 932, $1043(1834)$. 
the armed forces, ${ }^{26}$ services which have been continuously financed by Congressional appropriations to the present day. ${ }^{27}$ Chapel services are also compulsory in the service academies at West Point and Annapolis. ${ }^{28}$

Likewise, tax exemption of religious institutions, and the use of town halls and other public buildings for religious purposes in off-hours, ${ }^{29}$ without discrimination, were accepted governmental patterns in the era contemporaneous with the adoption of the First Amendment. Jefferson himself, in planning the University of Virginia, a great public institution, made provision for rooms for religious worship; ${ }^{30}$ and as Rector of the University, he proposed and there was established a voluntary plan as follows:

Should the religious sects of this State, or any of them, according to the invitation held out to them, establish within, or adjacent to, the precincts of the University, schools for instruction in the religion of their sect, the students of the University will be free, and expected to attend religious worship at the establishment of their respective sects, in the morning and in time to meet their school in the University at its stated hour. ${ }^{31}$

Madison was on the Board of Visitors which approved Jefferson's plan.

Government cooperation with or encouragement of religion, without preference and without interference with individual freedom, has also found expression in exemptions granted to ministers under laws relating to military service. ${ }^{32}$ A further and recent expression of the uninterrupted chain of evidence of the American attitude in general toward religion occurred in President Truman's Inaugural Address of January 20, 1949:

We believe that all men are created equal because they are created in the image of God. From this faith we will not be moved. ${ }^{33}$

Our first president likewise stressed the indispensable connection between religion and private and public felicity. ${ }^{34}$

The Supreme Court of the United States, in the notable opinion in Holy Trinity

${ }^{20}$ I STAT, 223 (I791).

${ }^{27}$ See Sen. Rep. No. 376, 32d Cong., 2d Sess. I-4 ( 1853 ).

${ }^{28}$ ReG. FOR THE U. S. CoRPS OF CADETS 47 (1947): "Attendance at chapel is part of a cadet's training; no cadet will be exempted. Each cadet will receive religious training in one of the three principal faiths: Catholic, Protestant, or Jewish."

U. S. Naval Acadexry REg., Art. 430I(b): "Midshipmen shall attend church services on Sundays at the Naval Academy Chapel or at one of the regularly established churches in the City of Annapolis." Id. Art. 430I (a): "Daily, except on Sundays, a Chaplain will conduct prayers in the messhall, immediately before breakfast." See McCollum v. Board of Education, 333 U. S. 203, 254-255 (I948), Reed, J., dissenting.

${ }^{20} \mathrm{See} 34$ A. B. A. J. 705 (1948); Nichols v. School Directors, 93 Ill. 61 (1879). Thirty-three states continue to permit sectarian groups to use school buildings in off-hours. See The State and Sectarian Education 36 (N. E. A. Research Bull. 1946).

, so Ig The Writings of Thomas Jefrerson 4II, 4I4-4I7, 449-450 (Mem. ed. I904); 3 Henry S. Rindall, Life of Thomas Jefferson 470-47I ( 1858 ); see McCollum v. Board of Education, 333 U. S. 203, 245-246 (I948), Reed, J., dissenting.

a1 19 The Writings of Thomas JefFerson 449 (Mem. ed. 1904).

${ }^{32} 54$ STAт. 887 (1940), 50 U. S. C. App. $\$ 305$ (d) (1946).

ss 95 Cong. Rec. 490 (Jan. 20, r949).

si I James D. Richardson, Messages and Papers of the Presidents 220 (1896). 
Church v. United States, compiled a multitude of examples to underscore the religious background of American social and legal institutions, and concluded:

... no purpose of action against religion can be imputed to any legislation, state or national, because this is a religious people. ...

There is no dissonance in these declarations. There is a universal language pervading them all, having one meaning. They affirm and reaffirm that this is a religious nation. These are not individual sayings, declarations of private persons: they are organic utterances; they speak the voice of the entire people. ...

If we pass beyond these matters to a view of American life as expressed by its laws, its business, its customs and its society, we find everywhere a clear recognition of the same truth. ${ }^{35}$

\section{Expenditures for "Public Welfare Services"}

Consistent with these views on the place of religion in our national life is the established rule that public funds may be used to pay for services rendered, notwithstanding the fact that the payment is to a religious organization. It is immaterial that tax-raised funds are paid to these individuals or organizations by way of reimbursement for money spent by them in furtherance of a public program. ${ }^{36}$ Illustrations of existing or possible arrangements of this type include payments by local governments to denominational hospitals, conducted by religious orders or otherwise, for medical services rendered to those entitled to receive such service at public expense; and expenditures by the Federal Government toward the construction of or additions to denominational hospitals, under the Hospital Construction Act. ${ }^{37}$

The same concept has been applied in the field of education. Federal Government payments to a denominational college for teaching or training draftees or veterans, even including training for the clergy, is authorized by the G-I Bill of Rights. ${ }^{38}$

This "public welfare" approach has been upheld by the Supreme Court. The Everson case holds that since the state is prohibited by the second clause of the First Amendment from hampering any citizens in the free exercise of their own religion, the state may not exclude children attending sectarian schools from the benefits of public welfare legislation, such as school busses, police and fire protection, and similar general government services. ${ }^{39}$ The opinion of the Court, written by Justice Black, recognizes that these services help children to get to church school, and that many parents would otherwise be reluctant to send children to these schools. ${ }^{40}$ The opinion continues:

${ }^{\text {ss }}$ Holy Trinity Church v. United States, I 43 U. S. 457, 465, 470, 47 I (I892).

so See Everson v. Board of Education, 330 U. S. I, 7 (1947); Carmichael v. Southern Coal \& Coke Co., 301 U. S. 495,518 (1937).

37 60 StAт. 1041, 42 U. S. C. $\$ \$ 29 \mathrm{I}(\mathrm{b}), 297 \mathrm{i}(\mathrm{g})$ (x946); cf. Bradfield v. Roberts, I75 U. S. 29I (1899).

${ }^{38}$ Servicemen's Readjustment Act, $\$ 400$ (b), pt. VIII (Ir), 58 STAT. 284,290 (1944), 38 U. S. C. foll. $\$ 739$ (1946). Federal Government machinery and personnel have also been used to negotiate contracts with the Bureau of Catholic Indian Missions to provide teachers for Indian schools paid out of Indian trust funds in the Treasury of the United States. Quick Bear v. Leupp, 210 U. S. 50 (1908).

${ }^{29}$ Everson v. Board of Education, 330 U. S. I, 18 (1947). 
... Of course, cutting off church schools from these services, so separate and so indisputably marked off from the religious function, would make it far more difficult for the schools to operate. But such is obviously not the purpose of the First Amendment. That Amendment requires the state to be a neutral in its relations with groups of religious believers and non-believers; it does not require the state to be their adversary. State power is no more to be used so as to handicap religions than it is to favor them. ${ }^{41}$

The Supreme Court has not cut off the application of this doctrine at the curb or the schoolhouse door. Justice Black's opinion cites with approval ${ }^{42}$, the earlier unanimous decision of the Court, upholding the Louisiana statute providing free textbooks without discrimination to pupils in denominational as well as public schools. ${ }^{43}$ The unanimous opinion in that case, written by Chief Justice Hughes, adopted the interpretation of the statute by the state court, that the appropriation was for the benefit of the children rather than the school, and was paid for secular rather than religious books, regardless of the school attended. Thus construed, the statute was held to be for a public purpose and valid under the Fourteenth Amendment.

The same reasoning should sustain federal expenditures in aid of children without discrimination in all types of schools meeting state standards, including expenditures for school lunches, ${ }^{44}$ school health services, ${ }^{45}$ and the like. ${ }^{46}$

D. Division of Responsibility between Church and State

From the foregoing rather summary review of the history of the First Amendment and of the legislative and judicial expressions thereon, it is reasonable to say that up to and including the Everson case development of public secular education and of religious education as conducted theretofore under varying circumstances. in the United States had met no constitutional obstacle on a national level; and that the responsibility of parents and of religious groups to participate in the education of the people, including religious education, had been fully recognized. It is also true that in America, where there can be no established religion and where full freedom in the exercise of religion is preserved, there has been at the same time public accommodation to or encouragement of religious teaching voluntarily undertaken by parental or group authority, short of governmental preference of any sect or interference with individual religious freedom.

This has been deemed consistent with Jefferson's figure of speech, "a wall of separation." The phrase is subject to elucidation in the light of its use by Jefferson to describe the inability of the Federal Government to infringe upon freedom of conscience and to establish or prefer a religion. In any event, what was submitted

${ }^{41}$ Ibid.

"Id. at 7 .

${ }^{43}$ Cochran v. Louisiana Board of Education, 28r U. S. 370 (1930).

460 STAT. 230, \$\$4, II(d) (3), 42 U. S. C. \$\$7753, 1759 (1946).

${ }^{45}$ S. 496,8 Ist Cong., Ist Sess. $57 \mathrm{~A}$ (1949).

${ }^{40}$ Cf. S. 246, 8rst Cong., rst Sess. $\$ 6$ (I949); SEN. R'Ep. No. r497, 79th Cong., 2d Sess. I7-20 (1946). See also Henty Rottschaefer, American Constitutional Law 633-634 (1939). 
for ratification was the text of the First Amendment, not Jefferson's figure of speech. ${ }^{47}$

To ignore the distinction in function between Church and State would be disastrous both to religious and to political freedom. But to make of the doctrine a rule of thumb to be invoked against every measure that brings Church and State into some cooperative relationship is to travesty an important principle and thus to make it more obscure. ${ }^{48}$

The "wall of separation" has not precluded cooperation. It was expressive of an American policy rather than of a constitutional determination of invalidity of all specific instances of cooperation. Certain things have consistently been clear under the First Amendment and under the policy of separation. There can be no established religion; there is "separation" in the United States rather than "merger" as in the old world at certain times and places; there can be no government interference with or coercion of the freedom of conscience and worship; there can be no control of the church within the machinery of the Federal Government such as might result from an established religion, and vice versa. These are examples.

Furthermore, the doctrine of separation from a policy standpoint might be said to extend beyond this to whatever seems wise to the state legislatures or state constitutional conventions, and to Congress, as particular problems arise. ${ }^{40}$ This policy keeps in mind the fundamental principle that the functions of the state and of religious institutions or groups, while ordinarily separate, are not antagonistic. It means that the state in the exercise of its natural temporal authority is not precluded from cooperating with parents or religious groups in education where responsibility touches parent, state, and such groups, provided this cooperation is in the realm of accommodation to the free exercise of religion guaranteed against infringement and does not prefer any religion. The guaranty of religious freedom is well nigh worthless if the state is obliged to manage its own temporal (including school) affairs in such a manner as to make religious education or exercise impracticable or

\footnotetext{
${ }^{4}$ Cf. Frankfurter, J., concurring, in Adamson v. California, 332 U. S. 46, 64 (1947): "Ricmarks of a particular proponent of the [Fourteenth] Amendment, no matter how influential, are not to be deemed part of the Amendment. What was submitted for ratification was his proposal, not his specch."

${ }^{48}$ F. Ernest Johnson, of Teachers College, Columbia University, at National Educational Association meeting, Atlantic City, 1947.

${ }^{49}$ It is noteworthy, for example, that Congress did not adopt a constitutional amendment proposed by President Grant, as follows: "No State shall make any law respecting an cstablishment of rcligion, or prohibiting the free exercise thereof; and no religious test shall ever be required as a qualification to any office or public trust under any State. No public property, and no public revenuc of, nor any loan of credit by or under the authority of, the United States, or any State, Territory, District, or municipal corporation, shall be appropriated to, or made or used for, the support of any school, cducational or other institution, under the control of any religious or anti-religious sect, organization, or denomination, or wherein the particular creed or tenets of any zeligious or anti-religious sect, organization, or denomination shall be taught. And no such particular creed or tenets shall be read or taught in any school or institution supported in whole or in part by such revenue or loan of credit; and no such appropriation or loan of credit shall be made to any religious or anti-religious sect, organization, or denomination, or to promote its interests or tenets. This article shall not be construed to prohibit the reading of the Bible in any school or institution; and it shall not have the effect to impair rights of property already vested. ..." H. Res. $x, 44$ th Cong., Ist Sess. (1876). See McCollum v. Board of Education, 333 U. S. 203,218 D. 6 (1948).
} 
to limit such education or exercise to Saturday or Sunday. It need hardly be added that the nonreligious and those of divergent religions are free in the exercise of their nonreligious or divergent religious life. -

\section{E. Effect of the Everson and McCollum Cases}

We come now to the McCollum decision and an additional discussion of the majority opinion in the Everson case. Certainly the views thus far expressed are consistent with the conduct of the government before the McCollum case. They are likewise consistent with the pronouncements of the Supreme Court in the "public welfare" cases, the relation of religion and government as expressed in the Holy Trinity case, and indeed the meaning of the establishment clause, as stated in the Reynolds ${ }^{50}$ and Beason ${ }^{51}$ cases. But what of the dicta or discussion in the Everson opinion and the decision in the McCollum case? The great significance of the discussion in the Everson opinion is that it was used as the basis of decision in the McCollum case. It related to the first clause of the First Amendment, the "establishment" clause, and reads in part:

The "establishment of religion" clause of the First Amendment means at least this: Neither a state nor the Federal Government can set up a church. Neither can pass laws which aid one religion, aid all religions, or prefer one religion over another. Neither can force nor influence a person to go to or to remain away from church against his will or force him to profess a belief or disbelief in any religion. No person can be punished for entertaining or professing religious beliefs or disbeliefs, for church attendance or nonattendance. No tax in any amount large or small can be levied to support any religious activities or institutions, whatever they may be called, or whatever form they may adopt to teach or practice religion. Neither a state nor the Federal Government can, openly or secretly, participate in the affairs of any religious organizations or groups and vice versa. In the words of Jefferson, the clause against establishment of religion by law was intended to erect "a wall of separation between church and State." Reynolds v. United States, supra at 164 .

We must consider the New Jersey statute in accordance with the foregoing limitations imposed by the First Amendment. ${ }^{52}$

Nevertheless the Court, supporting its holding by the strongest reasoning, decided that while the "wall must be kept high and impregnable," "New Jersey has not breached it here." ${ }^{33}$ In the McCollum case which soon followed, however, the discussion of the scope of the establishment clause of the First Amendment contained in the Everson opinion was the basis of the decision that the released-time plan there involved offended that clause although the New Jersey bus regulation had not. The Court, after describing the factual situation presented by the McCollum case, said:

This is beyond all question a utilization of the tax-established and tax-supported public school system to aid religious groups to spread their faith. And it falls squarely under the

${ }^{80}$ Reynolds v. United States, 98 U. S. I 45, I65-I66 (I878).

EI Davis v. Beason, I33 U. S. 333, 342 (1890).

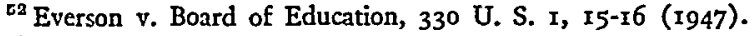

cs Id. at I8. 
ban of the First Amendment (made applicable to the States by the Fourteenth) as we interpreted it in Everson v. Board of Education, $33^{\circ}$ U. S. 1. ${ }^{54}$

The language of the Everson opinion that neither a state nor the Federal Government can pass laws which aid all religions, and that no tax in any amount can be levied to support any religious activity, needs construction and reconsideration in the light of the long-established practices set forth by Justice Reed in his McCollum dissent, such as, e.g., the maintenance of chaplains in the armed forces and exemption of religious properties from taxation.

Both majority and minority in the Everson case, in using the language just referred to in construing the establishment clause, worked into that clause at least the full breadth of Madison's position as to the policy which should be adopted by the State of Virginia in 1784 , a policy which was well beyond the scope of his position in the first Congress in I79I on the First Amendment itself. Furthermore, while thus agreeing in principle, the majority and minority of the Court divided on the application of the agreed principles to the Everson situation, though they combined in applying them in the McCollum case, with the exception of Justice Reed who there dissented. The point of division in application is that five justices saw no unconstitutional "aid" in the Everson case. This, combined with (x) the dissent of Justice Reed in the McCollum case because there he also saw no "aid," (2) the reservations expressed in that case by Justice Jackson, and (3) to a degree, those in the concurring opinion of Justice Frankfurter, leaves the future substantially open. For, while in all substance agreeing as to the correct principles to be applied in both cases, the justices disagreed sharply as to whether the bus regulation offended the agreed principles and constituted an invalid "aid" to religion; and the McCollum ruling is necessarily limited to the facts there presented. It is still extremely difficult to accept the theory that the traditional sorts of "aids" enumerated in the dissent of Mr. Justice Reed are unconstitutional. It would seem, therefore, that the meaning of "aid" in an inhibited constitutional sense remains open for decision case by case. Notwithstanding that the present Court has in terms defined the "establishment" clause in language quite broad, the questionable historical accuracy of its approach leayes the hope in many lawyers and scholars that that subject also is open for further consideration. In any event, there remains doubt as to the scope of application of the meaning given the first clause of the First Amendment and of the Court's broad and general language respecting unconstitutional aid. Especially significant is the concurring opinion in the McCollum case of Justice Jackson, who had dissented in the Everson case, believing there that the state had imposed "a direct, substantial and measurable burden on the complainant as a taxpayer to raise funds that were used to subsidize transportation to parochial schools." Justice Jackson found no substantial or measurable injury to complainant as a

${ }^{54}$ McCollum v. Board of Education, 333 U. S. 203, 210 (1948).

${ }^{56}$ Id. at 233 . 
taxpayer, and particularly warned against the sweeping language of the majority opinion and the sweeping relief prayed and seemingly granted:

While we may and should end such formal and explicit instruction as the Champaign plan and can at all times prohibit teaching of creed and catechism and ceremonial and can forbid forthright proselyting in the schools, I think it remains to be demonstrated whether it is possible, even if desirable, to comply with such demands as plaintiff's completely to isolate and cast out of secular education all that some people may reasonably regard as religious instruction ... The fact is that, for good or for ill, nearly everything in our culture worth transmitting, everything which gives meaning to life, is saturated with religious influences, derived from paganism, Judaism, Christianity-both Catholic and Protestant-and other faiths accepted by a large part of the world's peoples...

When instruction turns to proselyting and imparting knowledge becomes evangelism is, except in the crudest cases, a subtle inquiry. ${ }^{56}$

Justice Jackson argued against the Supreme Court's becoming a "super board of education for every school district in the nation," on a multitude of issues on which the Court "can find no law but our own prepossessions." Such a course, he emphasized, would 'likely make the legal 'wall of separation between church and state' as winding as the famous serpentine wall designed by Mr. Jefferson for the University he founded."'r7

The issue thus framed was subsequently raised with respect to the White Plains plan in New York, under which the problem of released time is handled in substantially the same manner as parental requests for excused absence for observance of religious holidays, confirmation classes, or other legitimate causes. Religious classes for one hour a week are conducted off school premises by duly constituted religious bodies. Children released for this instruction are dismissed in the usual way and the school authorities have no responsibility thereafter. There is no segregation under school auspices according to religious faith. Nonattending pupils remain in school doing significant school work. The school does not publicize or promote the program, gives no credit for attendance in religious classes, and does not supervise the classes in any way. The school requires only written consent of the parent, plus a report of attendance upon religious instruction for which release has been granted. The validity of this White Plains plan, upheld by the New York Court of Appeals long prior to the $M c$ Collum decision, ${ }^{58}$ was reiterated subsequent thereto, the Sureme Court of New York saying:

\footnotetext{
${ }^{20} I d$. at 235-236.

${ }^{57}$ Id. at $237-238$.
}

${ }^{68}$ Lewis v. Graves, 127 Misc. 135, 215 N. Y. S. 632 (Sup. Ct. 1926), $a f f d, 219$ App. Div. 233, 219 N. Y. S. 189 (1927), aff'd, 245 N. Y. 195, 156 N. E. 663 (1927), reargument denied, 245 N. Y. 620 , 157 N. E. 882 (1927). The Court of Appeals emphasized that "neither the Constitution nor the law discriminates against religion," and that under the White Plains plan, "denominational religion is merely put in its proper place outside of public aid or support." $245 \mathrm{~N}$. Y. I98, $156 \mathrm{~N}$. E. 664 . The Appellate Division, in upholding the plan, stated: "The commissioner and local authorities have adopted a benevolent policy, in which the interests of both parents and children are considered. They recognize that all education is not acquired in the schools; that, except for subjects legally prescribed, the parents may select the studies their children shall pursue; that it is the right of parents to direct the destiny of their children and guide them along paths of filial duty, as well as in those of obligation to the state ... and that a belief in religion is not foreign to our system of government." 2x9 App. Div. 238, 219 N. Y. S. 194-195. 
Historically and inherently the people of our country are predominantly a religious people. The Preamble to our own State Constitution is in these words: "We, The People of the State of New York, grateful to Almighty God for our Freedom, in order to secure its blessings, do establish this Constitution."

From such sources, however, the State derives no power to favor religious believers or to disfavor non-believers. The State must be neutral. Its "... power is no more to be used so as to handicap religions than it is to favor them." (Everson v. Board of Education, 330 U. S. I, p. I8.)

Fundamental is the right of the parent to rear his child in a particular religious faith, or to rear him as a non-believer if he so elects. Denial of this fundamental right to the parents now exercising the same through the medium of the New York released-time programs should certainly not be made on speculative grounds. Clearness and certainty are the factors that must control.

Judged in the light of those essential requirements, this court can neither in law nor in conscience hold that the programs here assailed are constitutionally condemned by the McCollum decision. ${ }^{59}$

It is noteworthy that McCollum $v$. Board of Education was the first decision in the Supreme Court of the United States striking down a legislative enactment, state or federal, on the ground of violation of the first clause of the First Amendment, concerning establishment of religion. That decision might be only the beginning of an extended line of authorities. The importance of the first clause of the First Amendment should not be permitted to imipair the vitality of the second clause, which guarantees the individual's right to freedom from official restraint, legislative, executive, or judicial, in matters of conscience, including the parents' responsibility for religious education of their children. The Supreme Court of the United States has gone to great lengths in protecting the "free exercise" of religion guaranteed by the second clause of the First Amendment, on the basis that it occupies a "preferred position" superior to other community or individual interests. ${ }^{60}$

\section{F. Teachers' Right to Wear Religious Garb}

Another issue, likewise requiring the harmonizing of the two great clauses of the First Amendment, has been raised regarding the employment as teachers in the public schools of members of religious orders who wear a religious garb. The Constitution prohibits any discrimination against teachers on the basis of their religious belief or mode of worship. ${ }^{61}$ Not even the criminal at the bar may be put to the proof of his religious doctrines or beliefs. As the Supreme Court said in the Ballard case:

${ }^{59}$ Lewis v. Spaulding, 193 Misc. 66, 85 N. Y. S. 2d 682, 689-690 (Sup. Ct. Albany Co., Nov. 12, I948).

${ }^{\circ 0}$ Saia v. New York, 334 U. S. 558 (1948); Marsh v. Alabama, 326 U. S. 501 (1946); Follett v. McCormick, 32 I U. S. 573 (I944); Murdock v. Pennsylvania, 319 U. S. ro5 (1943); Martin v. Struthers, 319 U. S. I4I (1943); Cantwell v. Connecticut, $3 \times 0$ U. S. 296 (1940); Douglas v. Jeannette, $3 \times 9$ U. S. 157 (1943); United States v. Ballard, 322 U. S. 78 (1944); Board of Education v. Barnette, 3 I9 U. S. 624 (1943). Cf. Kovaks v. Cooper, 336 U. S. 77 (1949).

${ }^{81}$ See United Public Workers v. Mitchell, 330 U. S. 75, roo (1947): "Appellants urge that federal employees are protected by the Bill of Rights and that Congress may not 'enact a regulation providing that no Republican, Jew or Negro shall be appointed to federal office, or that no federal employee shall attend Mass or take any active part in missionary work.' None would deny such limitations on congressional power ..." See also Railway Mail Ass'n v. Corsi, 326 U. S. 88 (1945); Shelley v. Kracmer, 334 U. S. $1,20-23$ (1948). 
Freedom of thought, which includes freedom of religious belief, is basic in a society of free men. Board of Education v. Barnette, 3I9 U. S. 624. It embraces the right to maintain theories of life and of death and of the hereafter which are rank heresy to followers of the orthodox faiths. Heresy trials are foreign to our Constitution. Men may believe what they cannot prove. They may not be put to the proof of their religious doctrines or beliefs. Religious experiences which are as real as life to some may be incomprehensible to others ...

The First Amendment does not select any one group or any one type of religion for preferred treatment. It puts them all in that position. Murdock v. Pennsylvania, 3 I9 U. S. I05. As stated in Davis v. Beason, I33 U. S. 333, 342, "With man's relations to his Maker and the obligations he may think they impose, and the manner in which an expression shall be made by him of his belief on those subjects, no interference can be permitted, provided always the laws of society, designed to secure its peace and prosperity, and the morals of its people, are not interfered with."62

There would seem to be no constitutional barrier to employment of a member of a religious order who otherwise qualifies as a teacher in the public schools under state law, who is subject to supervision and regulations on the same basis as other teachers in public schools, and who teaches the standard public school curriculum in regular school hours, merely because he or she belongs to a group who devote themselves to the religious life in a manner or to a degree different from many other persons.

The degree or mode of religious life outside the school or public office may not be substituted as a test for the holding of public office if a religious life itself may not be made such a test. Teachers in the public schools, since the earliest days of the Republic, have worn religious cloth of various denominations. ${ }^{63}$ A recent survey showed that members of religious orders in religious garb were employed as teachers to some extent in the public schools of sixteen states and territories. ${ }^{64}$

The Constitution does not require that every American be placed in a mold and dress like everyone else in order to enjoy the greatest of constitutional liberties-freedom of conscience, freedom of religion, and freedom of mode of worship. Concededly, the free exercise of religion is not "absolute," as, for example, in case of polygamy, breach of the peace, child labor, or refusal to bear arms. ${ }^{65}$ But the wear-

${ }^{\circ 2}$ United States v. Ballard, 322 U. S. 78, 86-87 (I944).

${ }^{63}$ See Hysong v. School District, I64 Pa. 629, 657-658, 30 Atl. 482,484 (1894): "The dress is but the announcement of a fact-that the wearer holds a particular religious belief . . But shall the education of the children of the commonwealth be intrusted only to those men and women who are destitute of any religious belief? .. . In many counties, there never was a time when ministers of Protestant sects were not frequently selected as teachers. Some of them wore in the school room, where children of Catholic parents were pupils, a distinctly clerical garb. When the office of county superintendent was first created, in 1854 , in many counties, preachers were chosen to fill the office. The present state superintendent of public instruction is a Protestant preacher . . . It was not assumed that the fact of membership in a particular church, or consecration to a religious life, or the wearing of a clerical coat or necktie, would turn the schools into sectarian institutions. In the 60 years of existence of our present school system, this is the first time this court has been asked to decide, as a matter of law, that it is sectarian teaching for a devout woman to appear in a school room in a dress peculiar to a religious organization of a Christian church. We decline to do so."

"The State and Sectarian Education 36 (N. E. A. Research Bull. 1946).

${ }^{05}$ In re Summers, 325 U. S. 56I (1945); see Prince v. Massachusetts, 321 U. S. I58 (1944); Chaplinsky v. New Hampshire, 315 U. S. 568 (1942). 
ing of religious cloth by public school teachers is not objectionable on any such grounds. This action is peaceful and violates no public policy. As stated by Justice Jackson in the flag salute case, "No official, high or petty, can prescribe what shall be orthodox in politics, nationalism, religion, or other matters of opinion or force citizens to confess by word or act their faith therein." 66

The proper harmonizing of the first and second clauses of the First Amendment lies in recognizing that the wearing of the religious garb by a teacher does not amount to state aid to religion prohibited by the first clause; but that to prohibit a teaching Sister from wearing the garb would infringe the free exercise of religion guaranteed by the second clause, and would establish an unconstitutional religious test as a qualification for public office.

This has been the judgment of all state courts which have passed on the precise issue in the absence of a general regulation or statute on the subject. ${ }^{07}$ The Everson and $M c$ Collum cases require no change in this line of decisions.

III

\section{Separation and Freedom in a Democracy}

The constitutional doctrine rests upon and should be confined to the meaning of the provisions of Article VI prohibiting any religious test for office or trust under the United States, the first clause of the First Amendment prohibiting any established religion or preference to any sect, and the second clause of the First Amendment prohibiting any interference with the individual conscience or free exercise of religion, which in turn protects the freedom not to believe. Jefferson's phrase had reference to this "wall of separation" contained in the Constitution, no more and no less.

There is, however, in addition, an American policy of separation of church and state which may express itself beyond constitutional provisions. This policy, like the constitutional provisions referred to, is a recognition of an ancient realization of the distinct functions of a temporal government and of a church concerned with the supernatural:

${ }^{80}$ Board of Education v. Barnette, 319 U. S. 624, 642 (1943).

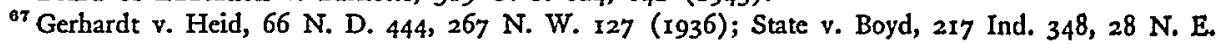
2d 256 (1940); Hysong v. School District, $x 64$ Pa. 629, 30 Atl. 482 (1894); New Haven v. Torrington, 132 Conn. 194, 43 A. 2d 455 (1945); Schwartz v. Consol. School Dist., unreported, Dist. Ct. Iowa, July 30, 1937; Brannon v. Castillo, N. Mex. Dist. Ct., 2d Jud. Dist. (1948); Millard v. Board of Education, 121 Ill. 297, xo N. E. 669 (1887). Compare Knowlion v. Baumhover, 182 Iowa 691, 166 N. W. 202 (1918) and Harfst v. Hoegen, 349 Mo. 808, I63 S. W. $2 \mathrm{~d} 609$ (1941), where the court did not proseribe wearing of religious garb as such, but held that the schools in question were parochial rather than public in character, because public school classes were held in one part of a building also used for parochial school classes during customary school hours; that the two were in fact operated as a single school of two departments, established and maintained to give religious training and the equivalent of a common school education during customary school hours; and that none of the public school authorities ever visited or supervised the schools or the teachers. See also Commonwealth v. Herr, $229 \mathrm{~Pa} .132$, 78 Atl. 68 (1910); O'Connor v. Hendrick, 184 N. Y. 421,77 N. E. 612 (1906) (upholding state statutes or regulations regulatung the dress of teachers and barring wearing of any religious garb or symbol). In Zellers v. Huff, the District Court of New Mexico recently refused to bar Catholic Sisters from teaching in public schools while wearing religious garb, but found that a number of Sisters involved in the case had come in conflict with state or federal law in other respects. Opinion from the bench, dated October 7, 1948, Decision, dated March ro, 1949. 
The spiritual power remains far removed from the temptations of the world, and, campaigning for God, does not mix into the affairs of the world, while on its side the secular power takes care not to undertake the direction of Divine things. By each one resting modestly in his place, each power avoids the pride of seizing absolute power, and thus holds a greater competence in the things that are his own. [St. Gelasius-Pope-d. 496.]

... In the thirteenth century, St. Thomas Aquinas had already found in Aristotle the philosophical foundation of the State as we know it today. He said that it is a perfect society, just as the Church is one also; that is, each fully contains within itself the means to fulfill its own distinct end. The State's end is the pursuit of temporal happiness; the Church's, the pursuit of eternal happiness; the State a natural society; the Church, a supernatural one. Each had its own sphere in which it operated. ...

As in so many other ways late in this third period, Leo XIII pioneered a new path by pointing the way back to the old one. It was he who recalled to the world the original formula of his predecessor, St. Gelasius I. Here is one way in which Pope Leo expressed the idea:

"The Almighty therefore, has appointed the charge of the human race between two powers, the ecclesiastical and the civil, the one being set over divine, the other over human things. Each in its kind is supreme, each has fixed limits within which it is contained, limits which are defined by the nature and special object of the province of each, so that there is, we may say, an orbit traced out within which the action of each is brought into play by its own native right."

But Leo continues:

"This distinction between Church and State, by the very nature of the two, requires cooperation as well, since each of these two powers has authority over the same subjects."

In such a separation of state and church, each has an educational responsibility, along with the primary responsibility of parents. Each of the three responsibilities may be fulfilled without infringement of the Constitution or of the policy of separation. Such fulfillment requires neutrality under the law as between the state and different religions; but it does not preclude the state from impartial cooperation with the efforts of parents and religious groups to aid in the spiritual development of the people if complete freedom of individual conscience is maintained and no religion is given state preference. Indirect religious aid which may be argued to flow from such arrangements for bus travel as were involved in the Everson case, or free textbooks, or free lunches, or free medical services, for example, are not within the inhibitions of the First Amendment. The Federal Constitution is not thereby troubled. A friendly and cooperative attitude toward religion is entirely consistent with religious freedom.

\footnotetext{
${ }^{40}$ Parsons, op. cit. supra note $\mathrm{r}$, at $88-89$, 90, 9I. See also the following statement by the Committee on Religion and Public Education, American Council on Education: "The core of meaning in the doctrine of separation of church and state we believe to be this: there shall be no ecclesiastical control of political functions; there shall be no political dictation in the ecclesiastical sphere except as public safety or public morals may require it." The Relation of Religion to Public Education-The Bastc Principles 25 (Nov. 1946), reprinted in 42 Religious Education 129, at r45-I 46 (1947).
} 